\title{
The Town and the Widow: The Journey of Elisabeth of Luxembourg to Pozsony
}

\author{
Renáta Skorka" - Boglárka Weisz"
}

vol. 8, 2019, 2, pp. 6-21

DOI: https://doi.org/10.33542/MAD2019-2-01

\begin{abstract}
Due to the vacancy on the Hungarian throne after the death of Albert I, King of Hungary, the pregnant queen set out for Pozsony (now Bratislava, Slovakia; Pressburg in German) to give birth to the future Hungarian king in the vicinity of the Habsburgs. However, Ladislas the Posthumous was born en route, in Komárom (now Komarno, Slovakia). The queen, having seized the Holy Crown of Hungary, went to Székesfehérvár to have her son crowned there in accordance with the Hungarian customs. Thus, her action preceded the crowning of Wladislas Jagiello, who had been invited to Hungary in the meantime by a group of barons to take the Hungarian throne. The city of Pozsony constantly supported Elisabeth and her court in realizing their plans. The reports of the queen's envoys and the account book of Pozsony help us reconstruct the exact course of events leading up to the queen's arrival in her beloved city.
\end{abstract}

Keywords: Kingdom of Hungary. Coronation in Székesfehérvár. Road network in Transdanubia. Habsburg dynasty. Jagiellonian dynasty. Pozsony (now Bratislava, Slovakia).

One of the almost inexhaustible groups of sources on Pozsony's urban history is represented by the city account books, which, in addition to the inner relations of the city, can provide ample information about the settlement's network of relationships. Based on the account books of Pozsony from 1439 and 1440, we seek to answer the question of how the city behaved in a troubled political situation. Following the death of King Albert, the expectant Queen Elisabeth of Luxembourg turned to the citizens of Pozsony, among other cities, looking for supporters, and her cry for help was answered. How did the city help the widow - who was not deterred even from stealing the Holy Crown - achieve her political ambitions in the face of opposition from many barons of the country? By what route did Elisabeth get to her beloved city after the heir to the throne was born and crowned? What did the queen give the city in return for all this?

Elisabeth of Luxembourg must have been on the estate of her cousin László Garai, ban of Mačva (banus Machoviensis), when she received notification that her husband Albert I, King of Hungary, had died in Neszmély, on 27 October 1439. At least, this is what the memoirs of the queen's confidential attendant, Helen Kottanner, inform us. ${ }^{1}$ The exact whereabouts of the queen is not known, but the chambermaid to the queen, who was at that time in Visegrád, refers to the Garai estate as being located "beyond Buda", 2 that is, to the south of Buda. The first concrete piece of information concerning the whereabouts of the widowed queen, who was already in the second half of her pregnancy, comes from 1 November. On that day she issued a charter in her own estate

The author is a member of the "Lendület" (Momentum) Medieval Hungarian Economic History Research Team (LP2015-4/2015) at the Hungarian Academy of Sciences, Research Centre for the Humanities (hereinafter HAS RCH), and associate research fellow at the HAS RCH Institute of History (skorka.renata@btk.mta.hu).

wh The author is head of the "Lendület" (Momentum) Medieval Hungarian Economic History Research Team (LP2015-4/2015) at the HAS RCH, and senior research fellow at the HAS RCH Institute of History (weisz. boglarka@btk.mta.hu). 
in Adony (in villa nostra Adon vocata), found in Fejér County. ${ }^{3}$ On November 3 , the widow was already in Óbuda, ${ }^{4}$ another settlement belonging to the queen's estate, where she issued a charter on the following day, as well. ${ }^{5}$ Since she was next reported to be in Visegrád on 9 November, ${ }^{6}$ it is probable that Albert was laid in his final resting place while Elisabeth was still in Óbuda, but certainly before she arrived in Visegrád. Albert's body was first transported from Neszmély to Győr in order to be taken from there to Vienna. However, this did not happen, and the royal corpse was finally taken to Fehérvár ${ }^{7}$ The reason for the hurried journey of the expectant mother to Visegrád was that Elisabeth firmly believed she was carrying the future king under her heart. She wanted to make sure that after his birth, her son would receive the crown jewels (and above all the Holy Crown) kept in Visegrád, which were required to make his reign legitimate. ${ }^{8}$ However, the Hungarian dignitaries did not want to waste time, either. Referring to the needs of the country and the Ottoman threat, they were unwilling to wait for the child to be born, and did their best to convince the widow queen to get married again as soon as possible. ${ }^{9}$

We may possibly give credit to Bonfini's account that the Hungarian political elite wanted to decide upon the person of the future husband at a parliamentary session, which also provided an excellent opportunity for them to put pressure on the queen in the matter of marriage. ${ }^{10}$ Elisabeth seemed willing to submit herself to the decision of the diet. She left Visegrád, ${ }^{11}$ the city that meant so much to her, and returned to the more centrally located city of Óbuda. She hardly left Óbuda between 27 November and 29 December. She issued charters in Buda (in the royal residence) only twice, on 7 December and on 23 December. ${ }^{12}$ Her long stay in Óbuda can probably be explained by the repeated postponement of the parliamentary session. From 3 January to 23 January 1440, however, the presence of the queen can be continuously and regularly demonstrated in Buda with a single intermission, ${ }^{13}$ and we can infer from this that a diet may have taken place at that time. Elisabeth seemingly

3 Adony is known to be one of the estates which was returned to Elisabeth's mother, Queen Barbara, by her husband Sigismund, King of Hungary, and her son-in-law Albert, Duke of Austria, in May 1424. According to a charter dated 25 May 1424, herds of horses also belonged to Adony (Adon cum equaciis ibidem habitis), see: Magyar Nemzeti Levéltár Országos Levéltára, Diplomatikai Levéltár [Hungarian National Archives, Diplomatics Archives] (hereinafter DL) 39284.

4 Óbuda was a property of the queen at this time.

5 Magyar Nemzeti Levéltár Országos Levéltára Diplomatikai Fényképgyújtemény [Hungarian National Archives, Diplomatics Photocopy Collection] (hereinafter DF) 239 735. DL 80700.

6 DL 13 457. Cf. IVÁN, A visegrádi vár története, 44.

7 Regesta Imperii XII, 275.

8 The royal couple entrusted the Holy Crown to György Bazini, their confidant and leader of Visegrád, in the summer of 1439. See: PÁLOSFALVI, Koronázástól koronázásig, 129.

9 PÁLOSFALVI, Koronázástól koronázásig, 129.

10 BONFINI, A magyar történelem tizedei, 166.

11 However, on 19 November 1439 she still issued her charter in Visegrád, see: DL 24532.

12 According to a misconception existing in Hungarian scholarly literature, Queen Elisabeth spent much of December 1439 and January 1440 in Buda. MOLLAY, Die Denkwürdigkeiten, 283, note 41. For the beginning of her stay in Buda, see: DF 250 205. For her last charter issued in Buda, see: DL 97 175. In chronological order, the two documents issued in Buda are: DF 213 039. DF 287582.

13 For her charter dated 3 January 1440, see: DF 281 455. For her charter dated 23 January, see: DF 270875. On the eve of Epiphany, she was in Esztergom (DF 239 741), but on the day of Epiphany she was again in Buda (DF 250 207). 
abided by the January decision of the diet, according to which the thirty-three-yearold woman was supposed to marry a sixteen-year-old "Christian peasant", ${ }^{14}$ Wladislas III, King of Poland. The widow apparently agreed to take this teenager as her husband in order to satisfy the political expectations and gain time, but in reality she had absolutely no intention of marrying the Polish king, whether she were to bear a boy or a girl. Spending no more time in Buda than necessary, she was in Visegrád again on 23 January. ${ }^{15}$ However, she did not stay there for a long time, either. She proved to be careful and cautious enough not to give birth to her child in Visegrád, as the Hungarian dignitaries expected her to do. It was her deliberate intention to get as far from Wladislas' supporters as possible amidst the changed political situation, which is why she wanted to give birth to her child in Pozsony, on the western border of the country, but still in Hungarian territory. Her decision was considerably influenced by the fact that King Albert I stated in his last will and testament on 23 October that if he had a son, he should have his seat in Pozsony. ${ }^{16}$

The queen was in close connection with the city of Pozsony after the death of Albert. Elisabeth had already sent a letter to the burghers of Pozsony on 3 November, a few days after her husband died, because they were apparently trying to postpone carrying out an order the king had issued on 29 September 1439: Nearly a month before his death, Albert had called upon the burghers of Pozsony to pay 4,000 golden florins to László Csetneki, Bishop of Nyitra (now Nitra, Slovakia) and governor (gubernator) to the Archbishop of Esztergom, for the leasing of tithes from the archbishop in the Pozsony cultellus. ${ }^{17}$ László Csetneki was supposed to hand over the sum in question to the Polish Miklós Stiborici, because the latter had lent Albert 7,000 golden florins until Saint Martin's Day (11 November) to cover the costs of organizing the defence of the kingdom against the Ottomans and other enemies. ${ }^{18}$ On 18 October, the king warned the citizens of Pozsony from Esztergom that their delay in paying the money was causing harm to the country and its inhabitants (land and leut darumb scheden emphiengen). ${ }^{19}$ The burghers of Pozsony obviously made every effort to postpone handing over this hefty sum of money, so with regard to the imminent deadline of repayment, on 3 November, Elisabeth called on them to pay the 4,000 golden florins to Csetneki without delay. ${ }^{20}$

One day after the deadline, on 12 November, Elisabeth wrote another letter to the burghers asking them to send two or three of them (duos aut tres ex vobis potiores) to her in Visegrád, who would take part in the negotiations. ${ }^{21}$ This event provided an excellent opportunity to talk about the claim for payment that must have been ignored by the burghers of Pozsony. The issue of the debt, however, had apparently not then been settled, as the widow sent a letter from Buda to Pozsony on 22 January. She demanded at this time for the much talked-about 4,000 golden florins to be handed

14 MOLLAY, Die Denkwürdigkeiten, 259.

DF 239747

6 DF 258374

17 Cultellus was a territorial unit of tithing.

18 DF 239728.

19 DF 239731.

20 DF 239735

21 DF 239736. 
over to Stiborici or one of his men. ${ }^{22}$ After returning to Visegrád, on 28 January, she called upon the city to pay Stiborici before 2 February. ${ }^{23}$ By the time Elisabeth's letter arrived in Pozsony, the widow had already made a plan to steal the Holy Crown from Visegrád, where it was kept, and to travel to this border town via Komárom. In order to dispel suspicion, the queen, who was in a very advanced state of pregnancy, left Visegrád well in advance. On 8 February, she reminded the citizens of Pozsony from Komárom that they had to pay 4,000 golden florins to Stiborici and told them again to send two or three delegates to her in Komárom. ${ }^{24}$

The burghers of the city seem not to have mobilized their efforts at the queen's request. Thus, on 15 February, Elisabeth sent an envoy to them in the person of Christoph Fladnitzer, ${ }^{25}$ who this time passed on the queen's message orally, instead of in writing. ${ }^{26}$ The words of the envoy, who had carried messages many times before, were effective. During the night of 17 February, the town dispatched two of its distinguished citizens, Bartholome Scharrach ${ }^{27}$ and Peter Jungetel, ${ }^{28}$ to Komárom. ${ }^{29}$ Somewhat later, Hans Leitgeber and Ludwig Königsfelder ${ }^{30}$ also visited the queen, and we also know that they certainly did not arrive empty-handed. According to the account books, they delivered wine to the court of Elisabeth. ${ }^{31}$ The queen was about to leave Komárom in the morning hours of 21 February. The wagons and servants were ready to set out for Pozsony when the woman went into labour one week early. The stealing of the Holy Crown from Visegrád was also scheduled for the time of their departure to Pozsony, so Helene Kottanner arrived in Komárom with this crown jewel just as Ladislas was born. ${ }^{32}$

The former plans had to be reconsidered because of the unexpected turn caused by the early birth of the child. Due to the queen's confinement to bed after childbirth, her journey to Pozsony had to be postponed, especially since there was harsh wintry weather at the end of February. ${ }^{33}$ Therefore, the widow's court had to settle in Komárom for a long

22 DF 239746.

23 DF 239 747. For the details of the conflict, see: C. TÓTH - LAKATOS - MIKÓ. A pozsonyi prépost és a káptalan viszálya, 177-178.

24 DF 239748.

25 Christoph Fladnitzer was appointed by Ulrik Cillei as the leader of Sopron in 1440. ENGEL, Magyarország világi archontológiája, 416.

26 DF 239749.

27 Bartholome Scharrach was the lord mayor of Pozsony in 1429, as well as the judge of Pozsony from 1433 to 1435, and from 1449 to 1450 . He was also a councillor in Pozsony from 1435 to 1436, from 1437 to 1439 , and from 1446 to 1447. MAJOROSSY, Egy határ menti szabad királyi város, 465-466. ORTVAY, Geschichte, 419.

28 Peter Jungetel was a councillor in Pozsony from 1439 to 1440, from 1444 to 1445, and from 1447 to 1448. He was also the lord mayor of Pozsony from 1442 to 1444, and the judge of Pozsony from 1450 to 1452. ORTVAY, Geschichte, 422, 454. MAJOROSSY, Egy határ menti szabad királyi város, 466.

29 Archív hlavného mesta SR Bratislavy [Archives of the Capital of the Slovak Republic, Bratislava], Magistrát mesta Bratislavy [Bratislava Town Hall] (hereinafter MMB), K 2. (Komorná kniha [Chamber books] 1439-1440) fol. 178v. (here and henceforth according to the old page numbers, 358).

30 Ludwig Königsfelder was a councillor from 1436 to 1437, from 1438 to 1439, and from 1443 to 1444. He was the judge of Pozsony from 1442 to 1443, from 1447 to 1450 , and from 1467 to 1468 . He was the lord mayor of Pozsony from 1453 to 1454, from 1457 to 1460 , and from 1465 to 1467 . ORTVAY, Geschichte, 423, 451. MAJOROSSY, Egy határ menti szabad királyi város, 466.

31 MMB K 2. fol. 179r. (359).

32 MOLLAY, Die Denkwürdigkeiten, 266.

33 The Account Book of Pozsony records that a ship had to be cut out of ice on 3 February, see: MMB K 2. fol. 93r. (183). 
period of time. Elisabeth's last charter issued in Komárom was dated 11 May 1440,34 which indicates a stay of over three months in Komárom, in possession of the illegally obtained Holy Crown. The citizens of Pozsony were informed about the birth of Ladislas by two messengers. They obviously also made it clear to the burghers that the city did not have to provide the queen and her retinue with hospitality yet. This must have been a huge relief for the burghers of Pozsony, who gave the two messengers twenty golden florins on 26 February. ${ }^{35}$ Of course, the city was still supposed to send presents to the queen. On 28 February, the wine steward (vaszieher) loaded two dreilings (ternarius) ${ }^{36}$ of wine from the cellar of the cannon master onto wagons. The city's coat of arms (schilt) was painted onto the barrels, which were delivered to the queen lying in childbed (kindlpett) by Ludwig Königsfelder and Hans Leitgeber. The two wagons carrying the wine were accompanied by two horsemen, and some boys also sat on the wagons to help with the loading and unloading of the barrels. ${ }^{37}$ In March, another delegation and further wagonloads of wine left Pozsony for Komárom. This time, on 7 March, the city sent Peter Jungetel to the queen, riding in the company of four attendants. The latter were supposed to help him cross the Danube. Winter was obviously still very harsh, as they had to cross the frozen river. ${ }^{38}$

Despite the difficult road conditions, Jungetel luckily made it to Komárom, on 9 March. ${ }^{39}$ The queen received him on the following day, and it turned out that the city had to dig a little deeper into its pockets. The queen's court in Komárom needed half a mázsa of oil, 40 the same quantity of figs (veigen), 100 herring, and one cask (Lagel) of sweet wine, as it was the middle of the forty-day Lent. After the meeting, the emissary from Pozsony did not leave "empty-handed", either. Elisabeth gave him one hundred golden florins for the costs for one of the urban slaughterhouses (Schlachtpruk) ${ }^{41}$ to be constructed at the time. ${ }^{42}$ Additionally, she gave Pozsony the mortar kept in the courtyard, and promised that she would also inform the count about this so as to prevent a conflict. ${ }^{43}$ On 22 March, Bartholome Scharrach and his four companions representing Pozsony returned to Komárom - perhaps bringing food for Lent - and stayed there until Easter. ${ }^{44}$ On 27 March 1440, Easter Day, the queen rose from childbed. According to Helen Kottanner's memoir, Matkó Tallóci and Imre Marcali arrived in Komárom shortly after this. Returning from their delegation in Poland, they carried news of the election of Wladislas as the King of Hungary, and tried again to persuade the queen to marry the

34 DL 13544.

35 MMB K 2. fol. 206v. (414).

36 It corresponded to approximately 2148 litres. Cf. BOGDÁN, Magyarországi ür-, térfogat-, súly- és darabmértékek, 173.

37 MMB K 2. fol. 96v. (190). MMB K 2. fol. 179r. (359). MMB K 2. fol. 195v. (392).

38 MMB K 2. fol 97v. (192). MMB K 2. fol. 103r. (203).

39 DF 241783.

40 This corresponded to 49.11 or 58.93 kilo. BOGDÁN, Magyarországi ûr-, térfogat-, súly- és darabmértékek, 456. During Lent, an increased amount of oil was consumed as a substitution for animal fat. Cf. KULCSÁR, Így éltek a lovagkorban, 94.

41 On the other slaughterhouses of Pozsony, see: MAJOROSSY, Community and Individuality, 6-32.

42 The slaughterhouse was built next to the Zwinger, between Wedritz Gate and Saint Martin's Tower. Cf. "Item auch an den tag II mawern in zwinger dy gemawert haben zwischen Bedriczer thar und Sannd Mertein thurm zu dem Schlachprukchel ydem XX d[enar] wienner facit XL d[enar] wienner." MMB K 2. fol. 110v. (220).

43 DF 241783.

44 MMB K 2. 179r. (359). 
Polish ruler. The widow had the two noblemen captured in Szőny, and after shipping them to Komárom, she took them into captivity. ${ }^{45}$ On 1 April 1440, Elisabeth wrote a letter to the city of Pozsony. Claiming that she needed an army (wir nimz volkch bedürffen werden), for which she wanted money (darczu wir gelt haben müssen), she asked the city to give her 2,000 golden florins in return for the tithes. ${ }^{46}$ The city did not hand over the entire sum of money then, but must have made a commitment to pay the money in instalments - perhaps 500 golden florins at a time, as will be discussed below - over the following months.

In April, however, not only considerable financial support was sent from Pozsony to Komárom, but we also know for certain that Paul Lang and Peter Jungetel, accompanied by six boatmen (schiffgeselle), shipped a cask of Malvasia wine, meat for frying and cooking (fleisch czu proten, czu syden), eggs (ayer), sugar (zokker), and oats (hafen) for the queen on 12 April. ${ }^{47}$ The widow received further help, as well: One day before Wladislas arrived on Hungarian soil - that is on the $22 \mathrm{April}^{48}$ - Elisabeth turned to the city in the hope of some more money to hire an army. ${ }^{49}$ She ordered the burghers of Pozsony to hand over 100 of the promised 500 golden florins to his emissary, Leonard Arberg, without delay, the rest of the money to be paid later. On the following day, the city sent Lienhard Horndl ${ }^{50}$ on a ship to Komárom, together with three sailors (schiffleute). The latter were also responsible for dragging the ship upstream (dieselbige zulln hinwider gegen dem wasser geczogen haben). ${ }^{51}$ The account book does not contain entries for goods connected with this delegation, from which we can infer that Horndl must have been charged with handing over the requested sum. By the time he arrived in Komárom, the queen and her chambermaid had already worked out their secret plan, namely that they would take the few-week-old Ladislas to Fehérvár and have him crowned there on the next major ecclesiastical feast-day, on the holy day of Pentecost (15 May)..52 The two women apparently shared their plan with Horndl, who hastily returned to Pozsony so that the city could appoint suitable delegates and dispatch them to the crowning city, Székesfehérvár.

Elisabeth was certainly still in Komárom on 11 May. ${ }^{53}$ She even addressed a letter to the burghers of Pozsony on that day, in which she expressed her gratitude to the city in case they had already given 500 florins to Christoph Liechtenstein. ${ }^{54}$ If, however, they had not done it yet, she asked them not to do so, but instead to send the money to her via her emissary, and give him an escort to Somorja (now Šamorín, Slovakia). ${ }^{55}$

45 MOLLAY, Die Denkwürdigkeiten, 267-269.

46 DF 239753.

47 MMB K 2. fol. 179v. (360).

48 Wladislas was in Késmárk (now Kežmarok, Slovakia) on 23 April 1440. SROKA, Itinerarium, 66.

49 DF 239758.

50 He was a well-known merchant in Pozsony. He was a councillor in 1440, and chamber count (comes camerae) to the Pozsony mint in 1442. Cf. ORTVAY, Geschichte, 455. WEISZ, A pozsonyi kamara felállítása, 30$32,46-47$.

51 MMB K 2. fol. 179v. (360). MMB K 2. fol. 110r. (219).

52 MOLLAY, Die Denkwürdigkeiten, 270.

53 Cf. DL 13544.

54 On 2 April 1440, Elisabeth informed the burghers of Pozsony of the arrival of Liechtenstein and other nobilities, and asked for time hoping that her meeting with Liechtenstein would also be beneficial to the city of Pozsony (DF 239 754). Her charter dated 5 April 1440 reported that Liechtenstein had arrived in Komárom, and promised to send help to the burghers of Pozsony (DF 239 756).

55 DF 239759. 
The letter must have been written when the queen still did not know the time of her departure to Fehérvár, because Somorja was situated along the road to Komárom. However, Liechtenstein was no longer in Pozsony when the queen's letter arrived in the city. On 12 May, the city gave him forty buns (semellen) and a cask of Malvasia, and Lienhard Horndl accompanied him to Köpcsény (now Kittsee, Austria)..$^{56}$ The road led via Köpcsény to Hainburg, or in the other direction, to Oroszvár (now Rusovce, Slovakia) ${ }^{57}$ and Győr. From Győr one could travel either to Komárom or to Fehérvár. According to a letter written by Stefan Ranes, judge of Pozsony, and Paul Lang, councillor, dated 17 May, in Komárom, Duke Albert VI and Liechtenstein missed the coronation (but this is in contradiction with the memoir of Helen Kottanner, who was present at the coronation ceremony). This may suggest that they travelled together, and after going from Pozsony to Köpcsény, Liechtenstein probably headed for Austria, instead of Oroszvár. It cannot be ruled out either that having returned from Komárom, Horndl told Liechtenstein to escort Albert, the guardian of Ladislas, to Fehérvár for the coronation. ${ }^{58}$

On the evening of 14 May, the envoys from Pozsony, namely Stefan Ranes, ${ }^{59}$ who was the judge of Pozsony, as well as Lienhard Horndl and Paul Lang, ${ }^{60}$ set out for Fehérvár on Horndl's coaches escorted by a few riders, ${ }^{61}$ to attend the coronation of Ladislas. According to the plans, they were to stay in Fehérvár for four weeks (until 11 June). ${ }^{62}$ The emissaries from Pozsony did not travel empty-handed this time, either. Their wagons were loaded with buns (semellen) made of wheat flour, two Küfels of salt (salcz), two large loaves of bread (proten), two lats of saffron (saffran), half a pound of pepper (piper), one Vierdling of ginger (ingber), and three pounds of olive oil (pawmöl).63 Stefan Ranes and Paul Lang collected István (perhaps István Rozgonyi) on the way, and that is why they arrived in Komárom as late as 17 May. ${ }^{64} \mathrm{Horndl}$, on the other hand, travelled directly to Fehérvár, so he probably arrived in time for the coronation, unlike the other two emissaries from Pozsony.

Elisabeth left Komárom for Fehérvár with her child late in the afternoon, on 12 May. ${ }^{65}$ She was accompanied by Ulrik Cillei, as well as Tamás Szécsi and his brothers. They spent the night in Tata. On 13 May, they arrived in Gerencsér, where they had "very

\footnotetext{
56 MMB K 2. fol. 195v. (392).

57 DF 239 369. Cf. KOVÁCS, A pozsonyiak vámmentessége, 362.

58 For events related to the guardianship by Albert beginning on 10 April 1440, see: LANGMAIER, Erzherzog Albrecht VI., 47-51.
}

59 Between 1437 and 1441 Stefan Ranes was the judge of Pozsony. MAJOROSSY, Egy határ menti szabad királyi város, 466.

60 In 1439, he was a councillor in Pozsony (ORTVAY, Geschichte, 454), and in 1451, he was the deputy lord mayor of Pozsony (MAJOROSSY, Egy határ menti szabad királyi város, 466).

61 MMB K 2. fol. 182v. (362).

62 Item am heiligen Pfingstag obund ist unser richter und der Linhart Horndl und Lanng Pauel ausgefaren mit etzlichen reitunden gesellen ken Weissenpurgkch zu unser genedigen frawen, der kunigin, als man unsern genedigen herren, den kunigk Lasla kronen schold, und beliben aus und untz in dy vierde wochen. MMB K 2 . 180r. (361).

63 MMB K 2. 180r. (361).

64 Historical Diplomatics 4. 14, Miscellaneous Records from the History of Győr V., Collectanea ad historiam civitatis Jaurinensis No. 5, kept in the János Czech Collection at the Department of Manuscripts and Rare Books, Library and Information Centre of the Hungarian Academy of Sciences (hereinafter János Czech Collection). We are indebted to Bálint Lakatos for calling our attention to this source.

65 According to the letter by Stefan Ranes, judge of Pozsony, and Paul Lang, councillor, dated 17 May, in Komárom, the queen left Komárom on Thursday evening (phincztag ze abent). János Czech Collection, 14. V. 5. 
poor accommodation, and wanted to eat, but didn't get much food there, because it was Friday", so they had to fast. They arrived in Fehérvár on the following day. ${ }^{66}$ On the holy day of Pentecost, on 15 May, Miklós Újlaki knighted Ladislas before the coronation, ${ }^{67}$ and the child was crowned king by Dénes Szécsi, Archbishop of Esztergom. During the coronation, the Holy Crown was held over the head of Ladislas by Ulrik Cillei, and Miklós Újlaki knighted several others. ${ }^{68}$ According to the sources, ${ }^{69}$ the coronation was also attended by Benedek, Bishop of Győr; Mátyás Gatalóci, Bishop of Veszprém; Helen Kottanner; Elisabeth, Princess Royal; Bertalan Frangepán; Tamás Szécsi and his brothers; the citizens of Fehérvár;70 András Harapki Botos; László and Imre, sons of Voivode János Tamási; ${ }^{71}$ Imre and László Kanizsai; ${ }^{72}$ the citizens of Buda and other unspecified cities; $^{73}$ the delegates of the Esztergom Chapter ${ }^{74}$ the sons of Benedek, son of Him Debrentei; ${ }^{75}$ and János Rozgonyi the Younger. ${ }^{76}$

On 18 May, Elisabeth issued a charter in Fehérvár, ${ }^{77}$ but on 27 May, she wrote a letter in Győr. ${ }^{78}$ According to Helen Kottanner, when Wladislas entered Buda (that is on 21 May), ${ }^{79}$ they were still in Fehérvár, and decided to leave the city on hearing the news. They wanted to go to Veszprém first, but the city did not let the queen in. The next destination was Győr, and the Bishop of Győr agreed to their entering. ${ }^{80}$ They set out after 21 May. The burghers of Pozsony sent three young men to wait for the city judge with a boat (zullen) on the Danube on the night of 23 May. They expected him to return from his visit to the queen in Fehérvár. ${ }^{81}$ This means either that the judge of Pozsony travelled to Fehérvár after a short detour to Komárom, or that the burghers of

\footnotetext{
66 MOLLAY, Die Denkwürdigkeiten, 270-271.
}

67 This account by Helen Kottanner is also supported by the report of the well-informed envoys of Pozsony, who were in Komárom at that time: vor der chrönung hat in [ti. Lasla] Wanfi Niclas ze ritter ge slagen. János Czech Collection, 14. V. 5.

68 MOLLAY, Die Denkwürdigkeiten, 272-273.

69 Pál Tóth-Szabó lists several nobilities and cities, but does not give the sources. Even though many of them must have truly attended the coronation ceremony, we mention only those whose presence can be supported by written sources. Cf. TÓTH-SZABÓ, A cseh-huszita mozgalmak, 174. Nevertheless, it is also possible that some of the persons mentioned by the narrative sources did not attend the coronation in reality.

70 MOLLAY, Die Denkwürdigkeiten, 273. According to the memoir of Helen Kottanner, Duke Albert VI was also present at the coronation ceremony, but the letter of the envoys of Pozsony contradicts this. Cf. János Czech Collection, MTA KIK Kézirattár 14. V. 5.

71 THURÓCZY, A magyarok krónikája, 269. BONFINI, A magyar történelem tizedei, 166. Thuróczy records in his chronicle that László Garai also attended the coronation, but the memoir of Helen Kottanner clearly refutes this. MOLLAY, Die Denkwürdigkeiten, 269.

72 BONFINI, A magyar történelem tizedei, 166.

73 HORVÁTH, Magyar Regesták, 59-60.

74 On 18 May, still in Fehérvár, Elisabeth ordered the castellan of Visegrád Castle (at the request of the delegates of the chapter who were visiting her) not to disturb the chapter and its tenants. DF 237810.

75 Elisabeth was in Fehérvár in May, when she had their charter regarding Szalónak Castle (now Burg Schlaining, Austria) transcribed by the Fehérvár Chapter. DL 100558.

76 PÁLOSFALVI, Rozgonyiak, 906.

77 DF 237810.

78 HÁZI, Jenő. Sopron királyi város története, 197-198. DF 202 696. DL 30312.

79 Joannis Dlugossii seu Longini canonici Cracoviensis Historiae Polonicae Libri XII. Tomus IV. Libri XI. XII. Cura et impensis Alexandri Przezdziecki. 1711, 734.

80 MOLLAY, Die Denkwürdigkeiten, 274.

81 MMB K 2. fol. 122.r. (243). 
Pozsony did not know that the judge had stayed in Komárom. From these two options, the latter is less likely. In any event, the judge did not arrive. Thus, the burghers of Pozsony hired again three boatmen to wait for the judge with a boat (zullen) on the night of 24 May, expecting him to return from Komárom. ${ }^{82}$ The judge did not arrive in Pozsony that night, either. Nevertheless, he must have made an appeal to the city, as on 25 May, buns (semellen) and bread (prot) were sent with a ship (schiff) and a sailor to Györ, in honour of the queen, who was in the company of the judge, Stefan Ranes, and Lienhard Horndl. ${ }^{83}$ The ship certainly got to Györ on the same day, so we can assume that the queen also arrived in Györ on 25 May or already on 24 May. According to the memoir of Helen Kottanner, their journey to Györ took two days ${ }^{84}$ and if we give credit to her account, then a courier was certainly able to get from Fehérvár to Pozsony in one day. Considering that the burghers of Pozsony assumed that the judge would arrive in their city at night, on May 23 (or on 24 May at latest), we have good reason to believe that they were informed by a messenger that the judge had started his journey back on 23 May. He certainly needed a whole day to get to Pozsony. If we accept what Helen Kottanner recorded, we can reconstruct the events as follows: on 22 May they were informed that Wladislas had entered Buda, and decided to take to the road on the following day. They arrived in Győr late at night, on 24 May. The judge of Pozsony must have sent a courier from there to Pozsony with a request, which was granted by the city on the next day.

According to the reconstruction made by György Györffy, the road connecting Györ and Fehérvár ran via the settlements of Pér, Dörög, and Örs (in Győr County) to Veszprém County. It continued there via Aszár and Bér to Fejér County, where it led via Sárkány, Dobos, Medved, Mór, Söréd, Igar, and Barc to Fehérvár. ${ }^{85}$ This means that it followed roughly the course of modern road No. 81. Late medieval toll stations, however, mark another route. After Győr, the next major toll station along the road to Fehérvár was Pázmánd. From there, the road must have run via Örs and Ászár to Hánta, 86 and then to Mór. In the Middle Ages, the section of road between Mór and Igar led through Orond (instead of Söréd) to Igar. (cf. the map)

On 13 December 1403, King Sigismund - confirming the privilege of Pozsony granting them exemption from tolls - referred to several toll stations where it was apparently difficult to enforce the exemption of Pozsony from the payment of tolls. These included Győr, Pázmánd (Pasuan), Hánta, Mór, and Fehérvár. ${ }^{87}$ In 1415, the king stepped up against the collection of tolls from the Transylvanian Saxons at Óvár, Mór, and Pázmánd (Pazon). ${ }^{88}$ Lajos Glaser identified Pazon mentioned in the charter with

\footnotetext{
82 MMB K 2. fol. 122v. (244).

83 MMB K 2. fol. 196r. (393)
}

84 MOLLAY, Die Denkwürdigkeiten, 275. According to a twelfth-century itinerary, the journey from Hainburg, "took two [days] to the castle called Rau. From that castle it was three days to the castle called Wzzenburch". In other words, one could get from Győr to Fehérvár in three days. KRISTÓ, Az államalapítás korának írott forrásai, 160.

85 Cf. GYÖRFFY, Az Árpád-kori Magyarország történeti földrajza. (The maps of counties Győr, Komárom, and Fejér).

86 The army of Henry III, Holy Roman Emperor, used this road in 1051. They set off from Bodajk, and passing through Bársonyos and Örs, they left the country. Cf. SRH I. 179. VESZPRÉMI, Az Árpád- és Anjou-kor csatái, hadjáratai, 102. For the road between Hánta and Ászár, see: Codex diplomaticus Hungaricus Andegavensis VII. Ed. Tasnádi Nagy Gyula. Budapest, 1920, 295.

87 DF 240491.

88 Urkundenbuch, 639-640. 
a desolate settlement (puszta) called Pázmán, found to the north of Dunaföldvár.89 However, if we take into account who the charter was addressed to, it seems more likely that the place in question was, in fact, Pázmánd, located in Győr County. King Sigismund named three people in connection with the three toll stations: Zubor oversaw the toll station at Mór, while Ulrik Wolfurt was in charge of the collection of tolls at Óvár. The castellan of Gesztes and Vitány Castles was mentioned in the charter, because the tolls collected in Győr County at Bőny, Pázmánd, and Szentvid belonged to Gesztes Castle, although the estates themselves did not form part of the lands of the castle. ${ }^{90}$ Based on these, it is clear that the charter of the Transylvanian Saxons, ${ }^{91}$ who normally travelled to the west via Fehérvár, refers to Pázmánd, which is found in Győr County.

A record from 1447 also shows that the route from Győr to Fehérvár passed through the toll stations at Mór, Orond, and Igar.92 In that year, János, son of István Rozgonyi, complained that people arriving from Pozsony and Györ bypassed these toll stations and took an illegal road ( falsa via) to Fehérvár via Zámoly (per possessionem Zamor) without paying tolls. ${ }^{93}$ All four settlements belonged to Csókakő, so they must have been owned by the same person who knew very well which roads the merchants were supposed to use when crossing his estate.

In order to cross Zámoly, travellers had to turn off the road connecting Győr, Bőny (Györ County), Igmánd (Komárom County), and Buda, and continue their way through Csákvár and Zámoly to Fehérvár. ${ }^{94}$ This detour had two possible courses. One of them passed through Bicske (Fejér County), which belonged to Vitány Castle and which was also a toll station. ${ }^{95}$ Nevertheless, there must have been another route that ran through the Környe toll station, which belonged to Gesztes Castle, and thus forked off from the road to Buda at Bánhida, ${ }^{96}$ the toll station of Vitány Castle. However, travellers arriving from the Vágköz and Csallóköz were not allowed to use this latter route, because it was regarded as an illegal road for them. ${ }^{97}$ We know this, because in 1457, Imre Somogyi and Mihály Kaplati, castellans of Gesztes Castle, and toll-collectors of the Környe toll station attacked some people at Nagydinnye, questioning whether they were using the right road. At the request of János, son of János Rozgonyi, however, the authorities of Komárom County decided the road running from the Danubian river-crossing place at Vas, through Bana, Nagydinnye, Ete, Apostol (Komárom County), and Mór (Fejér County) to Fehérvár was the legal and right road (iusta et vera via) to be used by people coming from the Vágköz or Csallóköz, whereas the road leading through Környe was an illegal

89 GLASER, Dunántúl középkori úthálózata, 150.

90 Cf. 1440: DL 13 900; 1453: DF 261 686, 1455: Wiener Stadt- und Landesarchiv, Hauptarchiv - Urkunden (1177-1526) 3608a. Accessed October 20, 2018. http://monasterium.net/mom/AT-WStLA/HAUrk/3608a/ charter.

91 Cf. WEISZ, Vásárok és lerakatok, 69.

92 The road along these toll sites was also used by the burghers of Pozsony and Buda. Cf. 1403: DF 240 491 , 1437: Codex diplomaticus Hungariae ecclesiasticus ac civilis I-XI. Studio et opera Georgii Fejér. Budae, 18291844, vol. X/7, 874. The road between Fehérvár and Igar was mentioned in 1374, CD, vol. IX/4, 627.

93 DL 14124.

94 On the road see: GYÖRFFY, Az Árpád-kori Magyarország történeti földrajza, vol. II-III. (Maps of counties Győr, Komárom, and Fejér).

95 Cf. DL 24732.

96 Cf. DL 24732.

97 However, this road was not a detour for every merchant or traveller, since toll stations were set up only along roads that were regarded as legal ones, at least for travellers arriving from certain directions. 
road ( falsa et iniusta via) for them..$^{98}$ After Mór, they certainly used the route crossing Orond and Igar, which was discussed above. János Rozgonyi stepped up in protection of the toll stations under his control, namely the ones at Mór, Orond, and lgar. This suggests that the road crossing Környe bypassed these toll stations, and certainly led through Csákvár and Zámoly to Fehérvár. ${ }^{99}$ Gesztes Castle - as well as the Környe toll station belonging to that - was in the possession of Miklós Újlaki. The assault launched by the castellans of Gesztes Castle may also be explained by the conflict between their lord, Miklós Újlaki, and János Rozgonyi and his brothers. This was not the only case when the castellans of Gesztes Castle took action against people whose way led through the toll stations of János Rozgonyi and his brothers. In 1461, for example, Simon Konde Újfalui, castellan of Gesztes Castle, and his men assaulted merchants travelling along the legal road (libera via) from Győr to Buda. The merchants were set upon between Bánhida and Szár, and were deprived of their goods as well as the money they were supposed to pay at the Bicske toll station, which belonged to János Rozgonyi. ${ }^{100}$

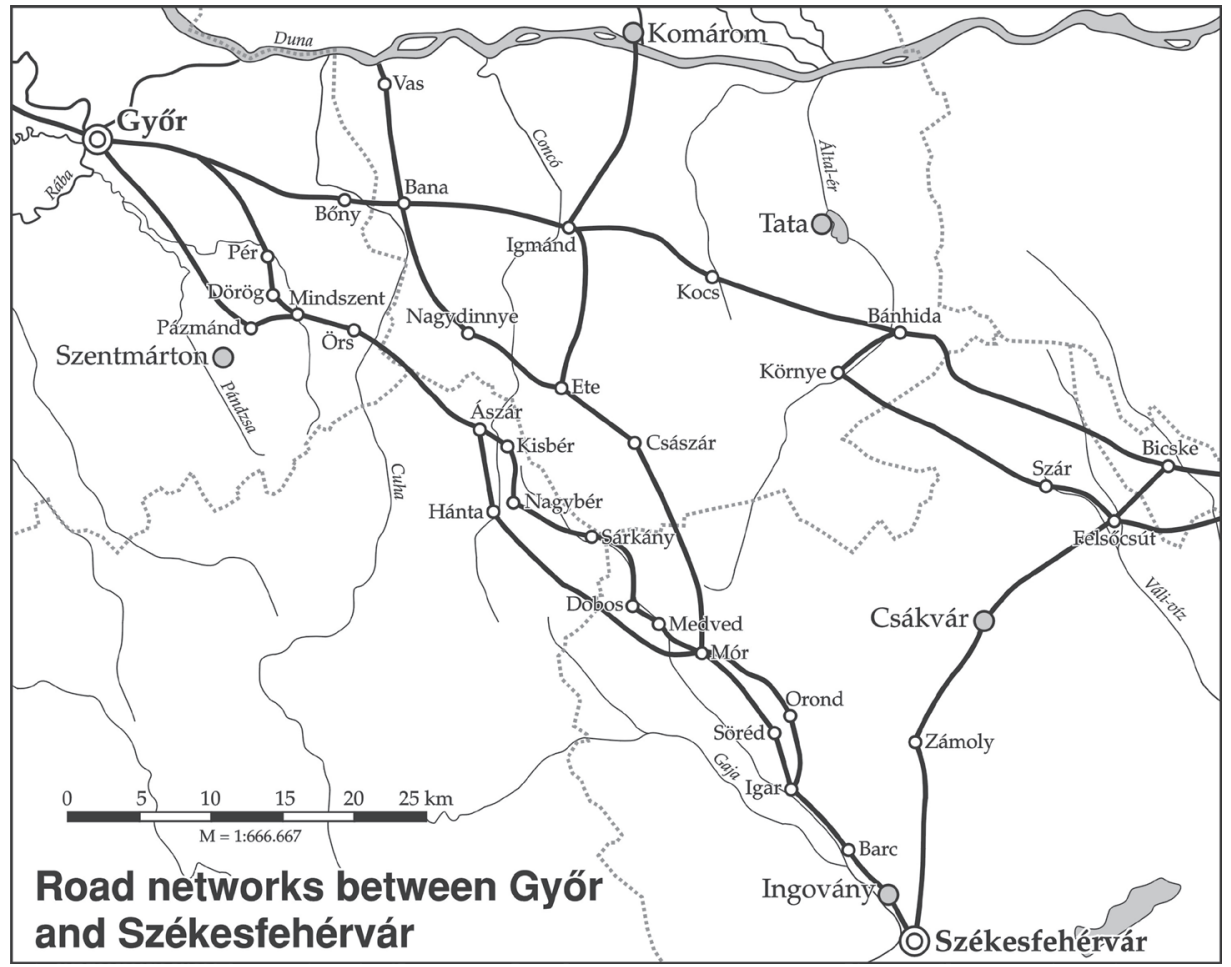

Figure 1: Road networks between Győr and Székesfehérvár

98 DL 93280.

99 This road was also used by the burghers of Fehérvár, who were attacked by János, son of István Rozgonyi on his estate at Környe, in 1446. They were deprived of their goods in the value of 800 golden florins, DL 88211. 100 DL 15 648. Bánhida was also a toll station belonging to Vitány Castle (DL 24 732). Thus the owner of the toll was János, son of János Rozgonyi, here as well. 
Which route must the queen have used when she travelled from Fehérvár to Győr? According to the account by Helene Kottanner, after crossing the Vértes Hills, they reached the plain. ${ }^{101}$ On the basis of her description, both routes are plausible. However, if we also follow the journey of the judge of Pozsony, we can notice that while the queen was in Fehérvár on 23 May, the judge was expected to return from his visit to the queen from Komárom on 24 May. This suggests that the queen travelled from Fehérvár to Győr via Komárom. This reasoning is not influenced by the question of whether the judge of Pozsony travelled from Komárom to Fehérvár, or waited for the queen in Komárom. The queen stayed in Györ for approximately two weeks, where her last charters were dated 7 June. ${ }^{102}$ It had already been decided in Györ that she would travel from there to the city of Pozsony. Her charter dated 2 June 1440 was written as part of her preparations for the journey. In this document, Queen Elisabeth ordered the Jews living in the city of Pozsony to pay their taxes due to the royal treasury for Pozsony for one year beginning with the date of the charter, which money was meant to be spent on guarding and preserving the city (pro subsidio custodie et conservacionis eiusdem civitatis nostre). ${ }^{103}$

The queen must have arrived in her beloved city, Pozsony, on 11 June 1440,104 because the city hosted a dinner in her honour firstly on that day, which was a Saturday, and for a second time on the Sunday. The account book keeps record of the ingredients used for the two meals, their quantities, and the amount of money spent on them. There is a clear difference between the ingredients of the meals served on the Saturday and Sunday. While on the Saturday, carp (kerphin), river-fish and small fish (pachfisch, klain fisch), and crayfish (kreussen) were served, on the Sunday, there were various kinds of meat (fleischs), including oxen (oxen), calves (kelber), ham (pache) and poultry - hens and chickens (alde, junge hüner). Additionally, wine, milk (millich), and sour cream (millichram) were put on the table only on the Sunday. Similarly, vinegar (essich) and oak wood (aichen holcz) were used for cooking only on this day. All this suggests that the Saturday was a fast day, which is supported by the fact that two types of cheese - matured and fresh (vierdige, hewrige kais) - were then offered, whereas on the Sunday, we find only matured cheese on the menu. Vegetables used in preparing the dishes, including leafy greens (gruen kraut), parsley (petersil), onions (zwiefel), shallots (aschlach), and other ingredients, such as salt (salcz), fat (smalz), eggs (ayer), pearl barley (gerstprein), coarse-ground flour (gries), and fine white flour (semel mel), as well as bakery products, like buns (semellen) and bread varieties (pollein prot, lab prot), were offered on both days. Fruit was also served on both days. However, on the first day they had only cherries (kyrschen), and there was a wider selection of fruit on the Sunday: cherries (kyrischen), apples (ephel), and - specifically for Princess Elisabeth (Queen Elisabeth's daughter) - strawberries (erdper).

Pozsony on many occasions helped the widowed Queen Elisabeth of Luxembourg on her long journey from Visegrád through Komárom to Székesfehérvár, and then via Győr to Pozsony. The city provided her with food, material assets, and an escort during her long journey. The queen, who had had her son crowned but could not secure him

101 MOLLAY, Die Denkwürdigkeiten, 275.

102 Codex diplomaticus domus senioris comitum Zichy de Zich et Vasonkeo. Vol. IX. Ed. Kammerer Ernő. Budapest, 1899, 12. DL 80 722, DL 80 723, DL 80724.

103 TELEKI, Hunyadiak kora, 84.

104 [...] amici dilecti civitas ipsa est ipsius domie regine, vosque similiter sue serenitatis estis. DF 239762. 
power, certainly assured the city of her continuing patronage. Siding with the queen, Pozsony undertook to stand up to the political majority of the Hungarian Kingdom and step into the focus of national politics. They were not even afraid of the possible military consequences of their actions.

\section{Appendix}

Archív hlavného mesta SR Bratislavy [Archives of the Capital of the Slovak Republic, Bratislava], Magistrát mesta Bratislavy [Bratislava Town Hall], K 2 (Komorná kniha [Chamber books] 1439-1440), fol. 298r-v. (according to the old page numbers: pp. 603-604). Photograph: DF 277058.

[fol. 298r]

\section{Czerung auf unser fraw dy künigin}

Item am sambstag vor Sannd Veitstag [11 June 1440] cham unser genedige fraw, dy künigin, hab wir geben czum obundessen umb manicherlay ding, als man das hernach geschriben sindt anno Domini millesimo quadringentesimo quadragesimo. ${ }^{105}$

Item umb $3^{106}$ grosse kerphin

Item umb pachfischs und ander klain fischs

Item umb 2000 kreussen

Item umb 1 hafen smalcz

Item und mer umb 2 hefen smalcz, paide umb

Item umb gruen kraut und petersil \}

Item umb 2 libra ayer

Item umb czwieffal und aschlach

Item umb 1 putten kyrschen

Item umb 4 virdige kais per $24 \mathrm{~d}$. Wienner

Item und umb 6 hewrige kais per $10 \mathrm{~d}$. Wienner

Item umb 4 kveffl salcz per 10,5 d. Wienner

Item umb 31 hafen klain und gros

Item umb 1 libra polleins prot per 1 newen $d$. facit

Item und umb 5 solidus semellen, ye czwa

per 1 newen denar, facit

Item und umb 32 gros lab prot per $3 \mathrm{~d}$. Wiener facit

Item am suntag vor Sannd Veitstag [12 June 1440] hab wir geben

umb fleischs czu dem mal umb 1 oxen vom Larentz Viertzker

Item von dem Pernhart Fleischker 1 guten pachen umb
7 ß d. wienner

1 lb. 24 d. w[iener]

3 ß 10 d. wien[er]

6,5 ß d. wiener

1 lb. $28 \mathrm{~d}$. [wiener]

$70 \mathrm{~d}$. wienner

$38 \mathrm{~d}$. w[iener]

$60 \mathrm{~d}$. wienner

3 B 6 d. wie[ner]

$60 \mathrm{~d}$. wienner

$42 \mathrm{~d}$. wien[er]

7 ß $24 \mathrm{~d}$. [wiener]

12 ß d. wien[ner]

5 ß d. wienner

3 ß 6 d. wien[er]

$3 \mathrm{fl}$. auri

2,5 fl. auri

Summa 9 l. 83 d. und 5,5 fl.

105 For the costs of the Saturday dinner in an inaccurate source edition, see: KNAUZ, A magyar egyház régi szokásai, 179-180.

106 The Roman numerals found in the text are written here as Arabic numerals. 
[fol. 298v]

Item von den Sigel von Teben 3 kelber per 50 new d. facit

Item umb 24 alde huenner per $10 \mathrm{~d}$. Wienner facit Item und umb 56 junge hüenner per 7,5 d. Wiener facit Item umb gerst prein Item und umb 5 vierdige kais per $24 \mathrm{~d}$. Wiener facit Item und umb 2 spen veril per $22 \mathrm{~d}$. Wienner facit Item umb gruen kraüt und petersil Item umb czwiefal und aschlach Item umb ephel Item umb millich und millichram Item umb erdper der jungen künigin Item umb gries und semel mel Item der jungen künigin und der alden umb 1 putten kyrischen und ander leuten Item umb polleins prot 400 lab per 1 new $\mathrm{d}$. facit Item und umb 300 semellen Item umb 4 flaschn mit wein der kunigin besunder von der Hanns Pewrin 2 flaschen paid zu 12 pinten per 9 d. Wienner und von den Hanns Feyrtag 2 flaschen, darin ist gegangen auch 12 pint per $12 \mathrm{~d}$. Wiener czum mall und czu ainen slof trunk facit Item umb ein fiertl essich und 2 pint per $15 \mathrm{~d}$. facit Item ain dreyling wein von dem czehent wein Item und umb 2 fuder aichen holcz
7 ßd. wienner $15 \mathrm{~d}$. w[iener]107 [without amount]108 7 Bd. $40 \mathrm{~d}$. wienner 0,5 lb. d. $44 \mathrm{~d}$. $50 \mathrm{~d}$. wienner $32 \mathrm{~d}$. wienner $40 \mathrm{~d}$. wienner $83 \mathrm{~d}$. wiener $24 \mathrm{~d}$. wiener 60 d. wienner

$70 \mathrm{~d}$. wienner 2,5 lb. d. wienner 7,5 ß d. wienner

1 lb. 12 d. wienner 6 B d. wienner 0,5 lb. d. wienner

Summa summarum 19 lb. $58 \mathrm{~d}$. wien. und 5,5 fl. auri

Summa 9 lb. 7 ß 5 d.109

\section{BIBLIOGRAPHY}

Archív hlavného mesta SR Bratislavy [Archives of the Capital of the Slovak Republic, Bratislava], Magistrát mesta Bratislavy [Bratislava Town Magistrate]

Czech János gyüjtemény Magyar Tudományos Akadémia, Könyvtár és Információs Központ, Kézirattár [János Czech Collection at the Department of Manuscripts and Rare Books, Library and Information Centre of the Hungarian Academy of Sciences]

Magyar Nemzeti Levéltár Országos Levéltára, Diplomatikai Levéltár [Hungarian National Archives, Diplomatics Archives]

Magyar Nemzeti Levéltár Országos Levéltára Diplomatikai Fényképgyüjtemény [Hungarian National Archives, Diplomatics Photocopy Collection]

Wiener Stadt- und Landesarchiv

107 There should be 225 Vienna denars, that is 7.5 solidi here.

108 The sum, that is 240 denars ( 1 libra), is missing.

109 This is 15 denars more than the listed sums. 
BOGDÁN, István. Magyarországi ür-, térfogat-, súly-és darabmértékek 1874-ig [Volume, surface, weight, and unit measures in Hungary to 1874]. Budapest: Akadémia Kiadó, 1991. BONFINI, Antonio. A magyar történelem tizedei [Decades of Hungarian history]. Translated by Péter Kulcsár, Budapest, 1995.

Codex diplomaticus domus senioris comitum Zichy de Zich et Vasonkeo. Vol. IX. Ed. Kammerer Ernő. Budapest, 1899.

Codex diplomaticus Hungaricus Andegavensis VII. Ed. Tasnádi Nagy Gyula. Budapest, 1920.

Codex diplomaticus Hungariae ecclesiasticus ac civilis I-XI. Studio et opera Georgii Fejér. Budae, 1829-1844.

ENGEL, Pál. Magyarország világi archontológiája [Secular archontology of Hungary] 13011457. I. Budapest: MTA TTI, 1996.

GLASER, Lajos. Dunántúl középkori úthálózata [The medieval road network of Transdanubia]. In: Századok, 1929, vol. 63, pp. 139-167, 257-285.

GYÖRFFY, György. Az Árpád-kori Magyarország történeti földrajza. Vol. II-III [The historical geography of Hungary in the age of the Árpáds]. Budapest: Akadémia Kiadó, 1987.

HÁZI, Jenő. Sopron királyi város története [The history of the free royal town of Sopron]. Part I, volume 3. Oklevelek és levelek 1430-tól 1452-ig [Charters and letters from 1430 to 1452], Sopron, 1924.

HORVÁTH, Mihály. Magyar Regesták a bécsi császári levéltárból [Hungarian regestae from the imperial archives in Vienna] 1118-1605. In: Történelmi Tár, 1861, series 1, vol. 9, pp. $1-96$.

IVÁN, László. A visegrádi vár története a kezdetektôl 1685-ig [The history of Visegrád Castle from the beginnings to 1685]. Visegrád: Visegrádi Mátyás Király Múzeum, 2004.

Joannis Dlugossii seu Longini canonici Cracoviensis Historiae Polonicae Libri XII. Tomus IV. Libri XI. XII. Cura et impensis Alexandri Przezdziecki, 1711.

KNAUZ, Nándor. A magyar egyház régi szokásai [Old customs of the Church in Hungary]. In: Magyar Sion, 1868, vol. 6, pp. 177-194.

KOVÁCS, Viktória. A pozsonyiak vámmentessége az Anjou- és a Zsigmond korban [The exemptions from paying tolls and customs duties of the burghers of Pozsony in the Angevin and Luxemburg periods]. In: WEISZ, Boglárka (ed.). Pénz, posztó, piac. Gazdaságtörténeti tanulmányok a magyar középkorról. Budapest: MTA BTK TTI, 2016, pp. 341-367.

KRISTÓ, Gyula (ed.). Az államalapítás korának írott forrásai [Written sources on the age of the foundation of the Hungarian state]. Szeged: Szeged Középkortörténeti Könyvtár, 1999.

KULCSÁR, Zsuzsanna. Így éltek a lovagkorban [Life in the age of chivalry]. Budapest: Helikon Kiadó, 2007.

LANGMAIER, Konstantin Moritz Ambrosius. Erzherzog Albrecht VI. von Österreich (14181463). Köln; Weimar; Wien: Böhlau, 2015.

MAJOROSSY, Judit. Community and Individuality in Medieval Urban Space: The Social Topography of Butchers Through the Case of Pressburg in Comparison. In: Czech and Slovak. Journal of Humanities Historica 2, 2011, no. 2, pp. 6-32.

MAJOROSSY, Judit. Egy határ menti szabad királyi város középkori igazgatásának vázlatos története [Sketching the urban administration of a free royal town at the border of the Kingdom of Hungary] (Tanulmány egy készülő pozsonyi archontológiai kötet elé) [Introduction to the "Archontology of Pressburg" in process]. In: Történelmi Szemle, 2015, vol. 57, no. 3, pp. 441-471.

MOLLAY, Károly. Die Denkwürdigkeiten der Helene Kottannerin. Die ältesten deutschen Erauenmemoiren 1439-1440 [The theft of the crown. The memoirs of Helene Kottanner]. In: Arrabona, 1965, vol. 7, pp. 237-296.

PÁLOSFALVI, Tamás. Koronázástól koronázásig. A korona elrablása és hazatérése (14401464) [From coronation to coronation: stealing and regaining the Hungarian Holy Crown (1440-1464)]. In: PÁLFFY, Géza (ed.). A Szent Korona hazatér. A magyar korona tizenegy külföldi útja (1205-1978). Budapest: MTA BTK TTI, 2018, pp. 125-169.

PÁLOSFALVI, Tamás. Rozgonyiak és a polgárháború [The Rozgonyis and the civil war] (14401444). In: Századok, 2003, vol. 173, pp. 897-928. 
ORTVAY, Tivadar. Geschichte der Stadt Pressburg. Vol. III. Pozsony: C. Stampfel, 1894.

Regesta Imperii XII. Albrecht II. 1438-1439. Bearb. Günther Hödl. Wien; Köln; Graz, 1975.

SROKA, Stanisław A. Itinerarium króla Wladyslawa [Itinerary of King Wladislas]. Vol. III.

Warszawa: Instytut Historii Pan, 2017.

TELEKI, József. Hunyadiak kora Magyarországon [The age of the Hunyadis in Hungary]. Vol. X. Pest, 1853.

THURÓCZY, János. A magyarok krónikája [Chronicle of the Hungarians]. Budapest, 2001. C. TÓTH, Norbert - LAKATOS, Bálint - MIKÓ, Gábor. A pozsonyi prépost és a káptalan viszálya [Conflict between the provost and the chapter of Pozsony] (1421-1425). Budapest: MTA TK, 2014.

TÓTH-SZABÓ, Pál. A cseh-huszita mozgalmak és uralom története Magyarországon [The history of the Czech-Hussite movements and rule in Hungary]. Budapest, 1917.

Urkundenbuch zur Geschichte der Deutschen in Siebenbürgen III. Bearb. Von Franz Zimmermann, Carl Werner, Georg Müller. Hermannstadt, 1902.

VESZPRÉMI, László. Az Árpád-és Anjou-kor csatái, hadjáratai [Battles and campaigns in the Árpád and Angevin periods]. Budapest: Zrínyi Kiadó, 2008.

WEISZ, Boglárka. Vásárok és lerakatok a középkori Magyar Királyságban [Markets and staples in the Medieval Hungarian Kingdom]. Budapest: MTA BTK TTI, 2012.

WEISZ, Boglárka. A pozsonyi kamara felállítása és működése a Zsigmond korban [The foundation of the Pozsony mint and its functioning during Sigismund's reign]. In:

KÁDAS, István - SKORKA, Renáta - WEISZ, Boglárka (eds.). Veretek, utak, katonák. Gazdaságtörténeti tanulmányok a magyar középkorról. Budapest: MTA BTK TTI, 2018, pp. 13-61. 